\title{
Rewriting Chaucer's Wife of Bath's Tale from Dryden, through Voltaire, to Niemcewicz: Medievalism or Modernisation?
}

\begin{abstract}
The aim of this paper is to track down the fortunes of cross-cultural transmission of The Wife of Bath's Tale in the course of the $18^{\text {th }}$ century. The continental interest in the tale was sparked off by Dryden's adaptation in his Fables, Ancient and Modern (1700). Dryden's version was rewritten by Voltaire as Ce qui plait aux dames (1764), which in turn was translated into Polish by Julian Ursyn Niemcewicz, and appeared in his collection Pisma różne wierszem i proza (Various Writings in Verse and Prose, vol. I, 1803) as Co sie damom podoba (What Pleases the Ladies). This trajectory of the Polish reception of Chaucer's tale confirms the characteristic pattern of adaptations and translations of English literary works into Polish - from English through French into Polish, though it is not typical of Niemcewicz's practice as a translator as he was one of the very few Polish translators translating directly from the English at the time. Thus, paradoxically to the $21^{\text {st }}$-century reader, the first, to my knowledge, Polish adaptation of The Wife of Bath's Tale does not reveal an interest in Chaucer but rather confirms the dependence of late $18^{\text {th }}$ - and early $19^{\text {th }}$-century Polish writers on French literary models. Likewise, differences in the representation of gender relationships between Chaucer's romance and its eighteenthcentury versions reveal that the agenda of the eighteenth-century adapters was rather catering to the taste of their contemporaneous readers than engaging with medieval English culture.
\end{abstract}

Keywords: Chaucer, The Wife of Bath's Tale, Voltaire, Ce qui plait aux dames, Julian Ursyn Niemcewicz, Co się damom podoba, translation, adaptation, rewriting, gender, medievalism.

While working on the reception of English literature at the turn of the eighteenth and nineteenth centuries and looking through the works of Julian Ursyn Niemcewicz, a Polish writer known as one of the first to translate directly from the English, I came across a tale strongly reminiscent of The Wife of Bath's Tale and yet at the same time strikingly different from Chaucer's version of the story. Julian Ursyn Niemcewicz's Co się damom podoba (What Pleases the Ladies), subtitled "a moral tale from Voltaire" represents an interesting case of cross-cultural trans- 
mission of narrative, involving different instances of medievalism if we accept Louise D'Arcens's understanding of medievalism as "the reception, interpretation or recreation of the European Middle Ages in post-medieval cultures". ${ }^{1}$ Niemcewicz's poem is a translation or an adaptation of Voltaire's tale Ce qui plait aux dames (1764), which is based on John Dryden's translation of Chaucer's Wife of Bath's Tale included in Fables Ancient and Modern (1700). The difference between the English versions of the story and its continental adaptations is already signalled by the titles. The title of Dryden's translation The Wife of Bath. Her Tale becomes replaced by Ce qui plait aux dames by Voltaire, which is translated as $C o$ się damom podoba? (What Pleases the Ladies?) by Niemcewicz. ${ }^{2}$ This change in the titles reveals a crucial difference of purpose between Dryden's "translation" of Chaucer's tale, and Voltaire's adaptation of Dryden. In his Preface to Fables Dryden openly declares that the aim of his adaptations is to make his contemporary readers familiar with Chaucer's tales and to establish Chaucer's reputation on par with that of great writers of antiquity. ${ }^{3}$ On the other hand, Voltaire and Niemcewicz do not seem to be aware of Chaucer's existence; the titles of Voltaire's tale and its Polish translation suggest light-hearted sexual pleasantry.

Voltaire composed his version of the tale in November 1763 at the age of 68 at Ferney, regarding the task as a respite from more serious intellectual efforts. The tale first circulated in manuscript among his friends and in 1764 appeared in the collection Contes de Guillaume Vadé, allegedly a posthumous publication of works by a recently deceased writer, but generally known to be a work of Voltaire. ${ }^{4}$ Stéphanie Bernier-Tomas has shown that Voltaire drew in his tale on the tradition of "French willingly licentious tale in verse" ("conte en vers français volontiers licencieux"). ${ }^{5}$ According to Patricia Hammons and Anne E. Duggan, a "libertine" or "licentious" tale evolved in the first half of the eighteenth century in France from the combination of fairy tales and elements of libertine novels, with the fairy elements essentially limited to the erotic. ${ }^{6}$ However, Bernier-Tomas points out

${ }^{1}$ L. D'Arcens, Introduction: Medievalism: Scope and Complexity [in:]The Cambridge Companion to Medievalism, ed. L. D'Arcens, Cambridge 2016, p. 1.

${ }^{2}$ I am using here the English translation of the title of Voltaire's tale, which appeared in Tobias Smollett and Thomas Francklin's edition of Voltaire's works (published between 1761-1765) The Works of M. de Voltaire. Translated from the French with notes historical and critical by T. Smollett, London 1765, vol. 35, p. 1-24. For Francklin as Smollett's collaborator on the edition, see Eugène Joliat, Smollett, Editor of Voltaire, "Modern Language Notes" 1939, vol. 54, n 6, p. 429-436.

${ }_{3}^{3}$ J. Dryden, Fables Ancient and Modern [in:] The Poems and Fables of John Dryden, ed. J. Kinslay, London 1969, p. 521-522. All quotations from Dryden are from this edition.

${ }^{4}$ S. Menant, Introduction [to:] Voltaire, Ce qui plaît aux dames [in:] Contes en vers. Editions critiques par Sylvain Menant in : Contes de Guillaume Vadé, CEuvres complètes de Voltaire 57B, ed. S. Menant, Ch. Mervaud et al., Oxford 2014, p. 23. All quotations in French from Voltaire are from this edition, referred to as Voltaire.

${ }^{5} \mathrm{~S}$. Bérnier-Tomas, Désinvolture morale et revendications féministes dans le conte en vers des Lumières, Féeries 2016, par. 10. http://feeries.revues.org/1001 (access: 24.08.2017). A.C. Hunter uses the term "conte libre", Le "Conte de la femme de Bath" en français au XVIII siècle, "Revue de la littérature comparée" 1929, n 9, p. 133.

${ }^{6}$ P. Hannon, A.E. Duggan, French Tales [in:] The Greenwood Encyclopaedia of Folktales and Fairy Tales, ed. D. Haase, Westport, Connecticut-London 2008, vol. 1, p. 379-388, p. 382. 
that the representation of sexuality tends to be different between French licentious tales in prose and in verse. Whereas in prose tales sexuality is often "vilified or mocked", tales in verse offer "an incitement to erotic pleasure". ${ }^{7}$ The celebration of sexuality in Voltaire's tale was acknowledged by François Bessire, the editor of the recent collection of Voltaire's erotic tales Ce qui plait aux dames et autres contes gallants (Arles: Actes Sud, "Babel", "Les Érotiques", 2008) through the choice of the term "a gallant tale" to refer to Voltaire's works in this collection.

Niemcewicz's translation of Voltaire's tale probably dates back to the years 1795-1796, when after the failure of the 1794 Insurrection against Russia and Prussia, in which he served as Tadeusz Kościuszko's aide de camp, he was imprisoned in St Petersburg. When he included it in volume 1 of his Pisma różne wierszem i proza (Various Writings in Prose and Verse 1803-1805), he was slightly apologetic about frivolity of Voltaire's story in his Preface ${ }^{8}$; nonetheless, he placed it between the translation of Pope's Rape of the Lock and Niemcewicz's own dumy, historical songs on Polish history.

As several critics have shown, Voltaire based his tale on Dryden's translation though the only acknowledgement of that is a comment in a letter to his friend Étienne Noël Damilaville that the tale "was partly drawn from an old romance" and that the subject was also presented by Dryden (19 December 1763). ${ }^{9}$ According to Donald Clive Stuart, there is no French romance on the subject, and Voltaire's tale does not bear resemblance to any other English versions of the story but Chaucer's and Dryden's. Although Voltaire claimed that he took the plot from an old romance, which would point towards Chaucer, lexical correspondences point towards Dryden. ${ }^{10}$ Niemcewicz followed Voltaire quite closely apart from the frame narrative and several instances of domestication. For the sake of brevity if I do not mention his translation directly, this means his version follows Voltaire.

Dryden's interest in Chaucer can be seen as medievalist from our contemporary perspective, but his alleged aim was modernisation. In his Preface he claims he needs to embellish Chaucer's English as it represents the early phase in the development of the language and thus Chaucer did not have sophisticated means at his disposal nor did he manage to use rhyme properly. ${ }^{11}$ Dryden's volume consists of texts by Chaucer (Palamon and Arcite; or the Knight's Tale, The Cock and the Fox; or, The Tale of the Nun's Priest, The Character of A Good Parson; Imitated from Chaucer, And Enlarged and The Flower and the Leaf at that time attributed

\footnotetext{
7 Bérnier-Tomas, op. cit., par. 16.

8 J.U. Niemcewicz, Przemowa autora [in:] J. Niemcewicz, Pisma różne wierszem i proza, vol. 1, Warszawa 1803 , p. xix.

9 "Est tiré en partie d'un vieux Roman, et a même étê traité en anglais par Dryden". Qtd. after D. Clive Stuart, The Source of Two of Voltaire's "Contes en Vers", "The Modern Language Review" 1917, Apr., vol. 12, n 2, p. 178, http://www.jstor.org/stable/3714124 (access: 3.04.2017).

10 D. Clive Stuart, op. cit., p. 178-180; S. Menant, Introduction [to:] Voltaire, Ce qui plaît aux dames [in :] Contes en vers. Editions critiques par Sylvain Menant in: Contes de Guillaume Vadé..., p. 26 and his notes to the text of Voltaire's tale. Ralph Nablow suggests that Thomas Otway's The Orphan, or the Unhappy marriage (1680) is Voltaire's another source of inspiration. See R. A. Nablow, Voltaire's Indebtedness to Otway in Ce qui plait aux dames, "Romance Notes" (1989-1990), p. 265-268.

11 J. Dryden, op. cit., p. 532-535.
} 
to Chaucer), Ovid, Homer, Boccaccio and Dryden himself. By placing them together in his Fables Dryden believed he would allow his readers to compare the merits of each poet. His choice of Chaucer's tales, he claimed in the Preface, was dictated by moral propriety, so he did not translate The Wife of Bath's Prologue as he found it "too licentious". ${ }^{12}$ It is thus ironical that Voltaire uses Dryden's translation as the main source for his licentious "tall tale" (conte pour écouter debout).

All the versions of the story, including Chaucer's, can be seen as medievalist since the contrast between the present of the story-telling and the past of the setting is clearly marked. Like $20^{\text {th }}$ and $21^{\text {st }}$ fantasy writers who use the medieval world as a conventional setting ${ }^{13}$, Chaucer, Dryden, and Voltaire reached for the setting in the distant medieval world in order to freely deploy supernatural elements in their work. Chaucer's and Dryden's Wife of Bath sets her tale in the times of the legendary King Arthur, and thus casts the genre of the tale as an Arthurian romance.

In th' olde dayes of the Kyng Arthour,

Of which that Britons speken greet honour,

$\mathrm{Al}$ was this land fulfild of fayerye.

The elf-queene, with hir joly compaignye,

Daunced ful ofte in many a grene mede.

This was the olde opinion, as I rede;

I speke of manye hundred yeres ago.

But now kan no man se none elves mo (1. 857-865). ${ }^{14}$

Dryden amplifies the description of the setting drawing his imagery from Shakespeare and possibly from Milton ${ }^{15}$; Chaucer's eight lines are expanded into twenty-three, and this is the general tendency of Dryden's version which replaces Chaucer's original 407 verses with 546.

In Days of Old when Arthur fill'd the Throne,

Whose Acts and Fame to Foreign Lands were blown;

The King of Elfs and little Fairy Queen

Gamboll'd on Heaths, and danc'd on ev'ry Green.

And where the jolly Troop had led the round

The Grass unbidden rose, and mark'd the Ground;

Nor darkling did they dance, the Silver Light

Of Phoebe serv'd to guide their Steps aright,

And, with their Tripping pleas'd, prolong'd the Night.

Her Beams they follow'd, where at full she plaid,

Nor longer than she shed her Horns they staid,

From thence with airy Flight to Foreign Lands convey'd.

${ }^{12}$ Ibid., p. 531-532; p. 536.

${ }^{13}$ C. Larrington, George Martin's A Song of Ice and Fire, HBO's Game of Thrones and the New Medievalism, plenary lecture at New Perspectives in English and American Studies, April Conference Fourteen Jagiellonian University in Krakow, 20-22 April 2017.

${ }^{14}$ All quotations from The Wife of Bath's Tale are from The Riverside Chaucer, $3^{\text {rd }}$ ed., ed. L.D. Benson. Based on The Works of Geoffrey Chaucer, ed. F.N. Robinson, Oxford 1988, p. 116.

${ }^{15}$ See A.C. Spearing, Rewriting Romance: Chaucer's And Dryden's Wife of Bath's Tale [in:] Chaucer Traditions: Studies in Honour of Derek Brewer, ed. R. Morse, B. Windeatt, Cambridge 1990, p. 243-244. 


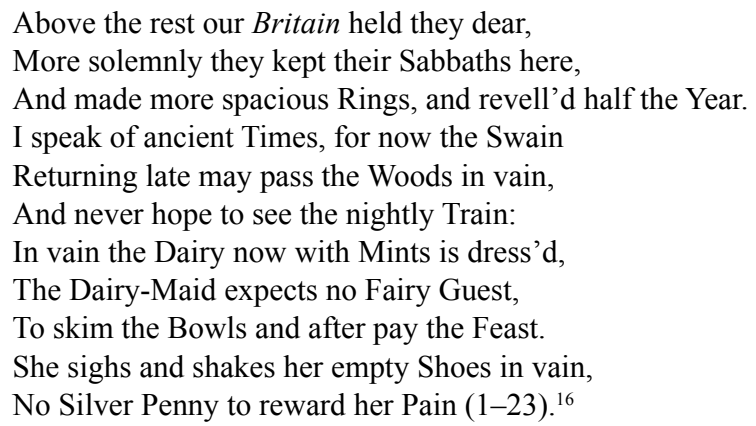

Voltaire's and Niemcewicz's version of the story is moved to France during the reign of King Dagobert, the Merovingian king of all Franks. That shift in the setting can be naturally attributed to the need for domestication, yet already here we notice a difference of emphasis. King Dagobert (604-639) can hardly be regarded as the French counterpart of King Arthur. In contrast to the virtuous Arthur he is known for his sexual profligacy, which signals the interest in the erotic in the tale. He is a historical character though Sylvain Menant points out that Voltaire would not consider Dagobert as a recognized historical character as he believed that it was impossible to carry out historical studies earlier than the times of Charlemagne. Therefore, as in Chaucer's and Dryden's versions, according to Menant, the choice of this ruler suggests, the legendary character of the tale. ${ }^{17}$

Voltaire and Niemcewicz discard the elaborate description of the medieval fairie setting present in Dryden. Instead they introduce a frame narrative, distancing the narrator and his audience from the time of the setting. The concern with the faerie past during the mythical Middle Ages of Dryden's opening is replaced by a statement that the story is proper for long winter's evenings, and the medieval setting is signalled first by the fact that the protagonist is a poor and noble knight named Jean-Robert.

This frame narrative signals the generic transformation from an Arthurian romance to a libertine tale, which is achieved primarily through the change of the narrator. The Wife of Bath's Tale is an Arthurian romance, though as A.C. Spearing points out, Chaucer himself transforms the conventions of the traditionally malefocused genre by having the story told from the female perspective. ${ }^{18}$ In Chaucer's tale the relationship between the storyteller and the tale enriches our enjoyment of the text, in Dryden's version Wife of Bath is only an ephemeral presence as the reader is not presented with her Prologue so she never fully comes to life. ${ }^{19}$

16 J. Dryden, op. cit., p. 778-779.

17 S. Menant, Introduction [to:] Voltaire, Ce qui plaît aux dames [in:] Contes en vers. Editions critiques par Sylvain Menant in : Contes de Guillaume Vadé..., p. 43, note 3.

18 A.C. Spearing, op. cit., p. 236-237.

${ }^{19}$ Her voice is perhaps most clearly heard in the closing lines, where she states her final envoi: "May Widows Wed as often as they can, / And ever for the better change their Man. / And some devouring Plague pursue their Lives, / Who will not well be govern'd by their Wives" (1. 543-546). J. Dryden, op. cit., p. 792. 
According to Spearing, Dryden "has undone Chaucer's rewriting of romance: the male viewpoint is restored to its central position". ${ }^{20}$ But in Dryden, as least nominally, the narrator remains female. In Voltaire's and Niemcewicz's versions, the voice of the first-person omniscient narrator is distinctly male, which naturally completely rids their versions of ironies and ambiguities deriving from the character of the Wife of Bath as the storyteller.

Voltaire's narrator is an eighteenth-century intellectual who wants to entertain friends with tales on long winter evenings:

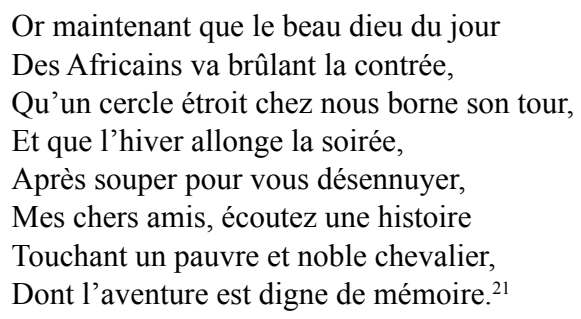

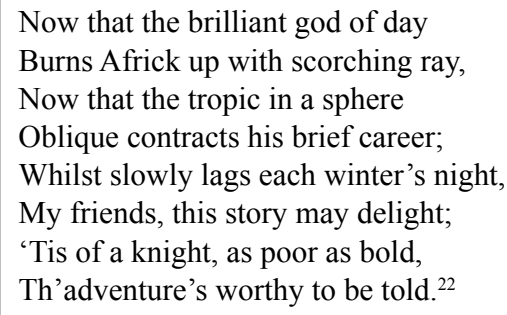

The rhetoric of Voltaire's opening verses is characteristic of neoclassicism and the Age of Reason with the sun personified as Apollo and the display of astronomical knowledge, but it is dropped later in the story in favour of the colloquial style appropriate for an oral tale. The narratorial voice returns at the end of the poem, expressing longing for the bygone days of the oral tradition of fairy tales, though instead of referring to them as "contes de fées", it calls them first "fables", and then "contes de sorcier" "tales of a sorcerer":

\begin{tabular}{|c|c|}
\hline $\begin{array}{l}\text { O l'heureux temps que celui de ces fables, } \\
\text { Des bons démons, des esprits familiers, } \\
\text { Des farfadets, aux mortels secourables! } \\
\text { On écoutait tous ces faits admirables } \\
\text { Dans son château, près d'un large foyer : } \\
\text { Le père et l'oncle, et la mère et la fille, } \\
\text { Et les voisins, et toute la famille, } \\
\text { Ouvraient l'oreille à monsieur l'aumônier, } \\
\text { Qui leur faisait des contes de sorcier. }{ }^{23} \text { [italics } \\
\text { mine] }\end{array}$ & $\begin{array}{l}\text { Happy the age! thrice bless'd mankind, } \\
\text { When tales like these belief cou'd find, } \\
\text { Of spirits hov'ring in the air, } \\
\text { Of demons who make men their care! } \\
\text { In castle close by roasting fire, } \\
\text { The daughter, mother, husband, sire, } \\
\text { The neighbourhood and all the race, } \\
\text { Attended with a wond'ring face, } \\
\text { Whilst, by the almoner, were told } \\
\text { Deeds done by sorcerers of old. } .^{24}\end{array}$ \\
\hline
\end{tabular}

Menant claims that in this tale Voltaire assumes the role of an old-fashioned storyteller at the fireplace in the evening such as represented in the frontispiece to Romans et contes, volume 3 of the Edition de Bouillon of his works

\footnotetext{
${ }^{20}$ A.C. Spearing, p. 241-242.

21 Voltaire, Ce qui plaît aux dames..., p. 43.

${ }_{22}$ Voltaire, What Pleases the Ladies, The Tales of William Vadé [in:] Works of M. de Voltaire, vol. 35, trans. T. Smollett, T. Francklin et al., London 1815, p. [11], Google eBook.

${ }^{23}$ Voltaire, Ce qui plaît aux dames..., p. 62

${ }^{24}$ Voltaire, What Pleases the Ladies..., p. 24.
} 
1778. ${ }^{25}$ Menant sees in this passage the nostalgia for the time of pagan superstitions, which may be seen as inconsistent with Voltaire's belief in reason, but can be explained by his conviction that childlike pagan beliefs were preferable to Christianity, which replaced them. ${ }^{26}$ This is confirmed by a touch of irony in the rhyme "l'aumônier", the almoner telling ancient stories, with "sorcier", sorcerer, which suggests close relationship between two traditionally mutually exclusive types of belief in the supernatural. Yet, the passage through its allusions to the oral tradition of fairy tales, may be seen not so much as a glorification but a parody of fairy tales. Stéphanie Bernier-Tomas suggests that it can be read as a "pastiche" of the frontispiece of the first edition of Charles Perrault's Contes de ma mère l'Oye (Tales of Mother Goose 1697). ${ }^{27} \mathrm{~F}$. Clousier's engraving to Mother Goose, based on Perrault's own design, represents a large woman in plain clothes, clearly a nurse, telling a story to a father and his two children at the fireplace. ${ }^{28}$ Voltaire imagines the almoner as having a larger social audience. An interesting take on this passage is offered by Charles Monnet and Jean Dambrun's engraving, mentioned by Menant. Voltaire is shown in the left-hand corner wearing a dark dressing-gown and a cap, which makes him look like a magician. His audience is placed on the left and consists of two elegant women and four men, the most imposing of whom is a friar. In its composition it looks like a mirror image of Clousier's print to Mother Goose. If the composition of Monnet and Dambrun's picture followed that of Clousier's, the friar, possibly the almoner, "monsieur l'aumônier", would be the story-teller as in the happy times of old in the passage quoted above. But in modern times it is Voltaire-the narrator who places himself in the position not of the almoner but of the sorcerer, questioning the established social and generic conventions as opposed to the moralistic narrator of Perrault's contes de fées.$^{29}$ This subversiveness is stressed by the fact that he refers to his tale not as "conte des fées", a tale of fairies or a fairy tale, which it literally is, but "conte de sorcier", placing the emphasis on the narrator as a magician.

In the final verses of his tale Voltaire stresses the contrast between the gone-by days of the faerie and the Age of Reason, and this can be seen as a reminiscence of Dryden's "Fairy Quires"(1.32) and "wicked Elves" (1.34) banished by the advent of Christianity ${ }^{30}$ :

${ }^{25}$ S. Menant, Introduction [to:] Voltaire, Ce qui plaît aux dames [in:] Contes en vers. Editions critiques par Sylvain Menant in: Contes de Guillaume Vadé..., p. 23-25.

${ }^{26}$ Ibid., p. 62, footnote 65.

${ }^{27}$ S. Bernier-Tomas, op. cit., par. 4.

${ }^{28}$ See Association Les Amis de Charles Perrault, Les frontispices des contes de ma Mère l'Oye, Oeuvres de Perrault et illustrations, 23 September 2014, http://amisdeperrault.canalblog.com/ archives/2014/09/23/30640565.html (access: 28.09.2017).

${ }^{29}$ Cf. S. Bernier-Tomas, op. cit., par. 5.

${ }^{30}$ J. Dryden, op. cit., p. 779. 
On a banni les démons et les fées; Sous la raison les grâces étouffées, Livrent nos cœurs à l'insipidité; Le raisonner tristement s'accrédite; On court, hélas! après la verité; Ah ! croyez-moi, l'erreur a son mérite. ${ }^{31}$
We of the marvellous are rifl'd,

By reason's weight, the graces stifl'd,

Have to th' insipid men consign'd

The soul by reas'ning is confin'd;

Still hunting after truth we go;

From error too some good may flow. ${ }^{32}$

In Voltaire's version, appropriately for the Age of Enlightenment, Reason has replaced Chaucer's friars and Dryden's priests. Menant suggests that these lines may be seen as an indirect attack on the "truth" not so much of Reason but of the Church $^{33}$, and turning back to Dryden as Voltaire's source text seems to confirm this claim. Yet the passage may be also read as an expression of longing for sexual pleasure, in Voltaire's tale associated with the realm of magic. "Error" in this case may be magic or sex, both of which sinful by the church's / reason's standard.

In the Polish translation Niemcewicz discards the neoclassical rhetoric of Voltaire's opening; his narrator directly announces he is going to entertain "a narrow circle" of his friends with an intriguing tale as "winter has come and the evenings are long". Voltaire's praise of the faerie as opposed to Reason at the end of the tale is replaced by the insistence on the comfort of fables or fairy tales as opposed to the "truth" of painful recent Polish history. Thus Voltaire's questioning of reason completely disappears and instead we are presented with an allusion to the failure of Kościuszko's Insurrection and the loss of Polish independence. The narrator is a Polish patriot trying to cheer up his compatriots in the times of national disaster:

\begin{tabular}{|c|c|}
\hline $\begin{array}{l}\text { Tu koniec mej powieści: nie próżnom się } \\
\text { trudził, } \\
\text { Jeżelim was Państwo nie znudził; } \\
\text { Lecz czymże innym mogłem was zabawić? } \\
\text { Dzieie prawdziwe aż nadto są smutne, } \\
\text { Nadto żałosne, okrutne, } \\
\text { I niebezpieczno prawdę iest wyiawiać. } \\
\text { Pewnieysze Bayki, baiek więc słuchaymy, } \\
\text { I lepszych czasów czekaymy. }{ }^{34}\end{array}$ & $\begin{array}{l}\text { Here my tale ends: I have not toiled } \\
\text { If I had not bored you; } \\
\text { But how else could I entertain you? } \\
\text { True history is far too sad, } \\
\text { Too painful and cruel, } \\
\text { And it is dangerous to reveal the truth. } \\
\text { Fables are more trustworthy, so let's } \\
\text { listen to fables, } \\
\text { And let's wait for better times. } \\
\text { [trans. M.C.] }\end{array}$ \\
\hline
\end{tabular}

Whereas Dryden does not introduce major changes to Chaucer's plot and actually elaborates the faerie setting, Voltaire, and Niemcewicz after him considerably modify the story, cut down on the descriptions of the faerie and develop the erotic elements. The generic transformation from an atypical Arthurian romance into a licentious tale in verse is reflected in the representation of gender relation-

31 Voltaire, Ce qui plaît aux dames..., p. 62.

32 Voltaire, What Pleases the Ladies..., p. 24.

33 S. Menant, Introduction [to:] Voltaire, Ce qui plaît aux dames [in:] Contes en vers. Editions critiques par Sylvain Menant in: Contes de Guillaume Vadé..., p. 62, note 65.

34 J.U. Niemcewicz, op. cit., p. 478. 
ships and this is particularly well visible in the rewritings of Chaucer's account of the rape of the maiden and of the conversation in bed between the Knight and his spouse. What women desire most turns out to be not so much sovereignty in general but being a mistress in her own house in particular with a strong innuendo that it implies being pleased in bed.

Chaucer's Wife of Bath offers the most clear and succinct report of the rape, in which there can be no doubt as to the guilt of the Knight:

He saugh a mayde walkynge hym biforn,

Of which mayde anon, maugree hir heed,

By verray force, he rafte hire maydenhed (1. 886-888). ${ }^{35}$

The perspective of Dryden's narrator is clearly male - he tries to win some sympathy for the "lusty Knight": his victim is not simply a "maid", but "a Damsel gay / In Russet-Robes" (1. 49-50). Her sexual attractions are vividly described:

Soon on the Girl he cast an amorous Eye,

So strait she walk'd, and on her Pasterns high:

If seeing her behind he lik'd her Pace,

Now turning short he better lik'd her Face (1. 51-54). ${ }^{36}$

Samuel Johnson used this passage as an illustration of the use of the word "pastern" to refer to "The legs of an human creature in contempt" ${ }^{37}$. and we can see that Dryden chooses the word to point to animal-like sexual attractiveness of the maid, and, disturbingly for the $21^{\text {st }}$ century reader, the horse-like "Pace" of the girl which first attracted the Knight's attention rhymes with "Face", the look at which seems to lead directly to the rape. The reference to the rape itself contains a certain glorification of male sexuality by rhyming "Youthful Fire" (1. 55) with "obscene Desire" (1. 56).

Dryden's rewriting of Chaucer's account of the rape prepared the ground for potentially misogynist representations of the country maiden in Voltaire's and Niemcewicz's adaptations. Marton and Marysia are conscious of their sexual attractiveness and quite willing to accommodate the sexual urges of the knight provided he pays the proper price. The crime of Voltaire's knight, named Jean-Robert, is altogether debateable. He offers twenty crowns, which is all the property he owns, to Marton, the maid, to yield to him. She ambivalently replies, "Sir, "tis too much honour"38 ("C'est pour moi trop d'honneur" (1. 48)) ${ }^{39}$ but he uses some pressure to subjugate her. In the process the eggs she has carried to the market get broken. Nonetheless, she raises an uproar only when she realizes she will not get the promised money as a monk has made away with the horse that carried JeanRobert's all worldly possessions. This makes her look more like a prostitute than a virtuous maiden. In Niemcewicz's version the maid called Marysia appears to

35 G. Chaucer, The Wife of Bath's Tale..., p. 117.

36 J. Dryden, op. cit., p. 780.

37 S. Johnson, A Dictionary of the English Language. A Digital Edition of the 1755 Classic by Samuel Johnson, http://johnsonsdictionaryonline.com/?p=6765 (access: 4.04.2017).

38 Voltaire, What Pleases the Ladies..., p. 13.

39 Voltaire, Ce qui plaît aux dames..., p. 45. 
be altogether compliant, saying "It's your honour's grace" ("Łaska to Pańska"40) to Robert's advances.

In the resolution of the tale, instead of being asked to choose whether he wants his wife to be beautiful but fickle, or ugly but faithful as in Chaucer's and Dryden's versions, Voltaire's knight (and Niemcewicz's knight likewise) has his sexual prowess tested. The conversation scene in bed is replaced by a narrative in which after being forced to marry the Loathly Lady, the knight is taken to her lowly and dirty cottage and offered a distasteful meal. Yet the sexually repugnant woman turns out to be an engrossing story-teller and he rather surprisingly finds himself enjoying her company. When she finally asks him to perform his marital duty, he proves to be equal to the task despite his physical repugnance. Satisfied, she implies that the power that women desire most is the control over sexual intercourse, and she commands him to open his eyes. He discovers himself to be in a palace and in front of him he sees the most enticing Beauty. The narrator explains that it was Fée Urgelle, who in times of old was a protector of French warriors. Menant suggests that while in the English versions of the story the object of the Knight's quest is the perfect marriage, Voltaire's Knight is looking for a perfect mistress. He manages to succeed in his final test thanks to his "infallible virility", which is a common characteristic of the protagonists of French verse tales in the $18^{\text {th }}$ century. ${ }^{41}$ The open preoccupation with sexuality combined with realistic detail and stronger satire directed against the clergy than in Chaucer and Dryden make the tale appear much more like a fabliau than a romance and this can be attributed to the fact that the fabliau can be seen as an antecedent of the French licentious tale.

Chaucer's tale is deprived of its highly-sexed narrator by Dryden and then in turn sexualized by Voltaire and Niemcewicz. Through this sexualisation the disturbing power rhetoric of Chaucer's original is restricted to the bedroom and thus rendered harmless. Even though overtly the title Ce qui plait aux dames might have led one to interpret the $18^{\text {th }}$ century versions as more focused on the feminine experience, Chaucer's female narrator makes a far better job of convincing us that this is a tale of "what pleases the ladies" and that is power - and not just being pleased in bed.

In conclusion, the four texts discussed in this paper reveal different forms medievalism can take. Already in Chaucer's tale, though from our perspective it is a medieval text, we can point to the use of mythical Arthurian Middle Ages as the setting for supernatural events. Dryden's version of medievalism could be perhaps termed modernisation as he tries to adapt Chaucer's tale to the poetic taste of his age. Voltaire's adaptation is also a form of modernisation, but it involves a generic transformation. As Hannon and Dunnan note, medieval romances were often used as sources of fairy-tales in the "golden age of French fairy-tales". ${ }^{42}$ On

40 J.U. Niemcewicz, op. cit., p. 465.

${ }^{41}$ S. Menant, Introduction [to:] Voltaire, Ce qui plaît aux dames [in:] Contes en vers. Editions critiques par Sylvain Menant in: Contes de Guillaume Vadé..., p. 27.

${ }_{42}$ Marie de France's Yonec provided the plot for Marie Catherine D'Aulnoy's L'oiseau bleu, P. Hannon, A.E. Duggan, op. cit., p. 379. 
drawing his plot from Dryden's translation of Chaucer, Voltaire, and Niemcewicz after him, follow the same practice, but instead of a fairy-tale present their readers with a libertine tale in verse. Thus, paradoxically to the $21^{\text {st }}$-century reader, the first, to my knowledge, Polish adaptation of The Wife of Bath's Tale does not reveal an interest in Chaucer but rather confirms the dependence of late $18^{\text {th }}$ - and early $19^{\text {th }}$-century Polish writers on French literary models.

\section{Bibliography}

Association Les Amis de Charles Perrault, Les frontispices des contes de ma Mère l'Oye, Oeuvres de Perrault et illustrations, 23 September 2014, http://amisdeperrault.canalblog.com/archives/2014/09/23/30640565.html.

Bérnier-Tomas S., Désinvolture morale et revendications féministes dans le conte en vers des Lumières, Féeries 2016, http://feeries.revues.org/1001.

D'Arcens L., Introduction: Medievalism: Scope and Complexity [in:]The Cambridge Companion to Medievalism, ed. L. D'Arcens, Cambridge 2016.

Clive Stuart D., The Source of Two of Voltaire's "Contes en Vers", "The Modern Language Review” 1917, Apr., vol. 12, n 2, p. 177-181.

Contes de Guillaume Vadé, Euvres complètes de Voltaire 57B, ed. S. Menant, Ch. Mervaud et al., Oxford 2014.

Dryden J., Fables Ancient and Modern [in:] The Poems and Fables of John Dryden, ed. J. Kinslay, London 1969, p. 521-522.

Hannon P., Duggan A.E., French Tales [in:] The Greenwood Encyclopaedia of Folktales and Fairy Tales, ed. D. Haase, Westport, Connecticut-London 2008, vol. 1.

Hunter A.C., Le "Conte de la femme de Bath" en français au XVIII siècle, "Revue de la littérature comparée" 1929, n 9, p. 117-140.

Johnson S., A Dictionary of the English Language. A Digital Edition of the 1755 Classic by Samuel Johnson, http://johnsonsdictionaryonline.com/?p=6765.

Joliat E., Smollett, Editor of Voltaire, "Modern Language Notes" 1939, vol. 54, n 6, p. 429-436.

Niemcewicz, J.U., Co się damom podoba [in:] J.U. Niemcewicz, Pisma różne wierszem i proza, vol. 1, Warszawa 1803.

Niemcewicz J.U., Przemowa autora [in:] J.U. Niemcewicz, Pisma różne wierszem i proza, vol. 1, Warszawa 1803.

Spearing A.C., Rewriting Romance: Chaucer's And Dryden's Wife of Bath's Tale [in:] Chaucer Traditions: Studies in Honour of Derek Brewer, ed. R. Morse, B. Windeatt, Cambridge 1990, p. 243-244.

The Works of Geoffrey Chaucer, ed. F.N. Robinson, Oxford 1988.

The Works of $M$. de Voltaire, translated from the French with notes historical and critical by T. Smollett, London 1765, vol. 35 .

Works of M. de Voltaire, vol. 35, trans. T. Smollett, T. Francklin et al., London 1815. 